\title{
Conflict Resolution through Consensus Building Approach in the Implementation of Bus Rapid Transit System
}

\author{
Fernando Lámbarry Vilchis ${ }^{1}$, Luis Arturo Rivas $\operatorname{Tovar}^{1} \&$ Mara Maricela Trujillo Flores ${ }^{1}$ \\ ${ }^{1}$ Sección de Estudios de Posgrado e Investigación de la Escuela Superior de Comercio y Administración Unidad \\ Santo Tomás, del Instituto Politécnico Nacional, Ciudad de México \\ Correspondence: Fernando Lámbarry Vilchis, Sección de Estudios de Posgrado e Investigación de la Escuela \\ Superior de Comercio y Administración Unidad Santo Tomás, Prolongación de Carpio 471, Colonia Plutarco \\ Elías Calles, Delegación Miguel Hidalgo C.P. 11340, México Distrito Federal. Tel: 57-29-60-00 (ext. 61607). \\ E-mail: flambarry@ipn.mx
}

$\begin{array}{rr}\text { Received: March 25, } 2012 & \text { Accepted: April 11, } 2012 \quad \text { Online Published: July 16, } 2012 \\ \text { doi:10.5539/ijbm.v7n14p1 } & \text { URL: http://dx.doi.org/10.5539/ijbm.v7n14p1 }\end{array}$

\begin{abstract}
The decisions on concessioned transportation in relation to the implementation of a new alternative to the existing one, especially in developing countries are a cause of debate and disagreement. In the absence of measures for solving these differences, the result is a lack of action that delays important decisions on this matter.

In light of the international literature, the rapid transit bus systems planning models, agree that for political purposes it is advisable to involve, the existing licensees that operates on what it will be the stroke of the corridor, the new transport system but they also refer as critical the way they will be included, if they are not included at all, they will politicallly resist the system. However, these models make little emphasis on the establishment of agreements between the key groups involved, while the consensus building models are not documented despite the prominence and importance that public transport has on the international agenda and the growing popularity and implementation of BRT. The purpose that guided this documental-reflexive research consisted on proposing a consensus building model within two of the principal interested: the affected dealers and government officials responsible for the implementation of the BRT system.
\end{abstract}

Keywords: bus rapid transit, consensus building, conflict resolution models

\section{Introduction}

The decisions on concessioned transportation in relation to the implementation of a new alternative to the existing one, especially in developing countries are a cause of debate and disagreement. In the absence of measures for solving these differences, the result is a lack of action that delays important decisions on this matter.

The decision-making to concession public transport involves the public and private sphere and it involves various interested parts (NGOs, government, transportation, citizens, etc.,) with divergent interests and experiences that make the decision-making process complicated. Group decision-making as pointed out by Regan, Colyvan \& Markovchick (2005), is often the result of a course of a laborious unstructured negotiation, that rarely gives repeatable results or strategies that are transferable to similar contexts. On the subject of consensus building, although the literature is abundant, as indicate Lámbarry, Rivas \& Trujillo (2009), the models are usually applied to the inside of an organization or between organizations in solving health problems, land ownership disputes, within international negotiations, public policies and even more on environmental issues (Petts, 1995; Stauffer, 2001; Susskind et al., 1999; Van derBelt, 2004; Regan, Colyvan \& Markovchick, 2005; Innes \& Booher, 2010).

On public transport, despite the prominence and importance that this issue has on the international agenda, due to the increasing and popular implementation in cities throughout the world system of bus rapid transit (BRT for its acronym in English) as a successful and sustainable alternative to the problematic situation of transport, nowadays there is no systematic approach to build consensus that integrates the different views among the affected groups of interest. 
Ideally, when implementing a new mode of transport, it must be analyzed and presented a narrow capital cost and a broad range capacity of profitable operations, it means a system that minimizes the cost and maximize the profitability of operating conditions, compares the passenger capacity in the transport modes against the capital cost, justifying in the first instance the reason of the famous and progressive implementation of the BRT system in many nations.

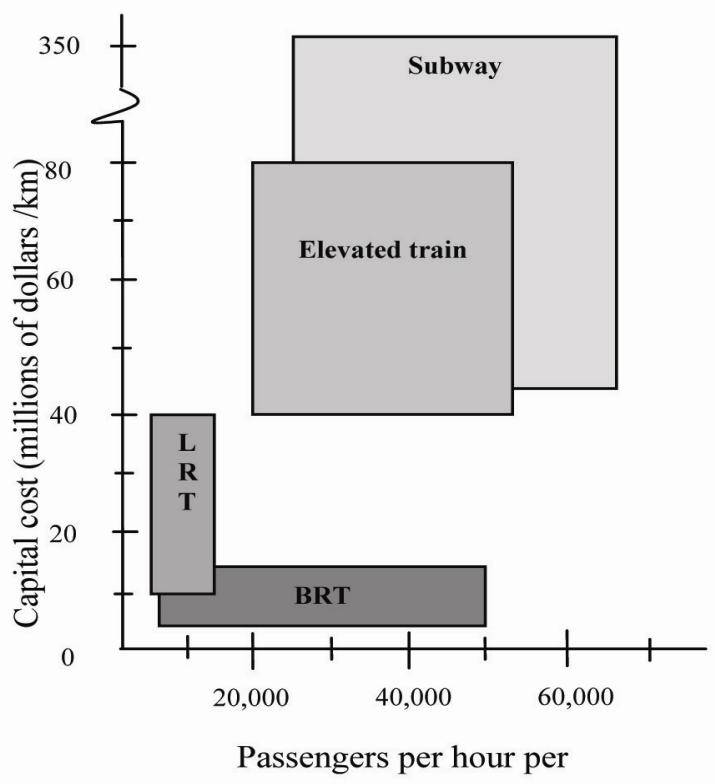

Figure 1. Passenger capacity and capital cost for mass transport options

Source: Institute for Transport and Development Policy (2007).

Note: The different sizes of the rectangles, are associated with relative risk and flexibility of each modality.

In relation to costs, the capital cost (infrastructure and property costs), BRT systems are typically in the range of 500.000 dollars per kilometre up to 15 million per kilometre, the average is still below the 5 million per kilometre, while the cost per kilometre of the Subway is between 50 and 350 million dollars (Institute for Transport Policy and Development, 2007). The capacity of passengers to transport (passengers per hour per direction, pphpd), depends on the percentage of passengers transported per vehicle, speed and time between vehicles as identified by the Institute for Transport Policy and Development (2007), however, the BRT ranges in capacities from 3.000 to 45.000 passengers per hour per direction (in the Subway is pphpd 25.000 to 90.000).

\section{Method}

This documentary is a reflexive research of the state of the art in consensus building models, performed in EBSCO databases, ABI Inform, Wiley, Questia as well as academic Google, in which it was decided to study the consensus building processes on the concessioned public transport perspective, particularly during the implementation rapid transit buses systems, which at replacing inefficient and outdated modes of transport, it is necessary through joint agreements, its acceptance and instrumentation, through the integration of various interest of the key groups involved, being the main affected the existing concessioned operators, to whom the BRT systems planning models agree and refer as necessary to involve, with the intention of minimizing political opposition to the project and to increase the public support for its successful implementation.

The research problem that grounded this research consisted that currently there is no systematic approach to building consensus for the implementation of BRT systems that integrates the different views among the involved groups of interest. So, the used research method, involved a review and analysis of documents, prepared by various international organizations, among which outstands the following bus rapid transit planning models: German Technical Cooperation Agency (2003), Transit Federal Administration (2003), Center for Sustainable Transport (2005) and the Institute for Transportation and Development Policy (2007), while similarly, for consensus building models among they predomine for its empirical evidence: Dalkey-Helmer (1963), Tree Bressen (1984), Butler (1987), Canadian Round Tables (1996), Susskind (1999), Seeds for Change (2009). There 
were two categories of analysis and their respective units:

1) BRT systems planning models: key groups identification and negotiation variables.

2) Consensus building models: stages and variables.

The data analysis was performed using Atlas.ti software Win 6.2, which as Pidgeon \& Henwood (1997) refers it, supports the coding and grounded theory building in Social Sciences. The purpose that guided this study was to propose a model of consensus building between two of the main interested: the affected dealers and government officials responsible for the implementation of the BRT system.

\section{Theoretical Framework}

Currently there are different procedures to solve conflicts which involve two or more affected parties in a wide sphere of contexts, which can be classified into two major groups, methods for dispute resolution and alternative methods for dispute resolution

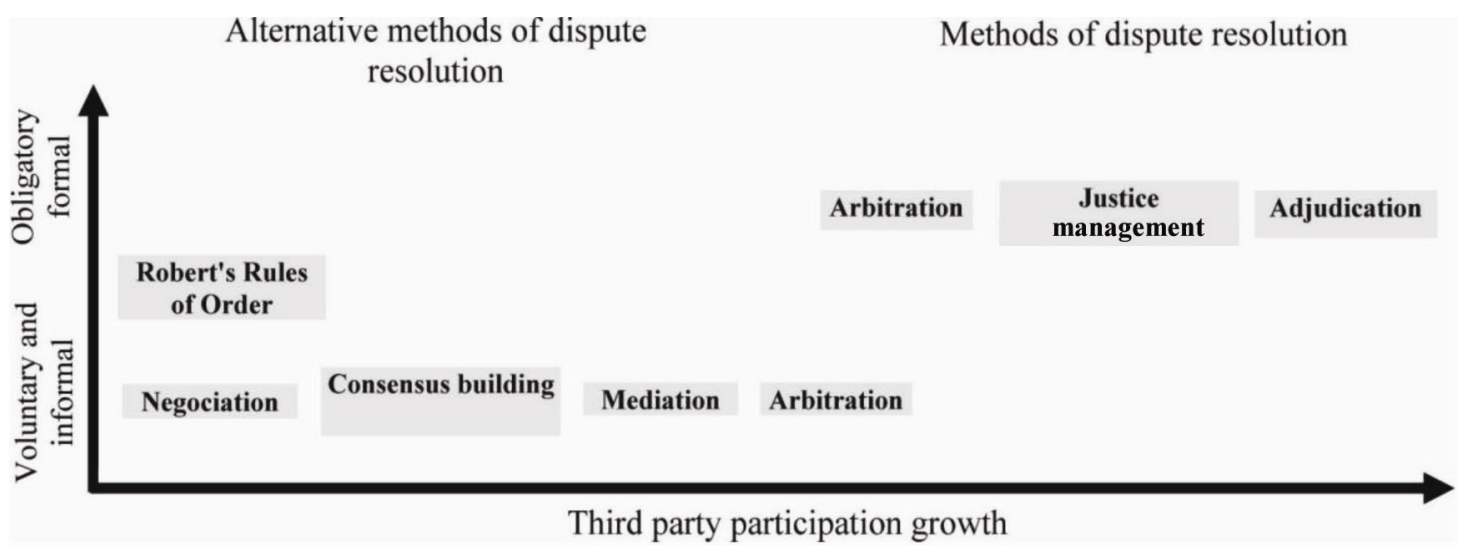

Figure 2. Taxonomy of dispute-conflict resolution

Source: own ellaborated

Note: The processes on the figure's left side, present the potential of preserving, restoring or establishing positive relationships between those involved and in economic terms there are usually not as expensive, while those in the center to the right tends to be more expensive, they are more formal and confrontational, where the relationships between those involved are rarely considered for its importance and its potential impact on the settled decision (Center for Democracy and Governance, 1998).

In the first one there is a legally binding judicial process settled in court, while in the other one, the process is voluntary (Center for Democracy and Governance, 1998). In the voluntary processes the aim is to develop mutually acceptable solutions either with assistance or without it, of an external and independent third party. In other cases, the dispute is submitted to an authorized third party for its resolution.

On Stage 1: The Delphi process traditionally begins with an open-ended questionnaire, that allows to gather specific information about a content of any area of the Delphi topics. On Stage 2: Each participant is given a second questionnaire and is asked to review the synthesized contents by the researchers according to the information gathered on Stage 1. As a result of the stage, there are identified areas of agreement and disagreement (Ludwig, 1994). At this stage the consensus began to be formalized and its results can be presented among the participants answers (Jacobs, 1996). On Stage 3: the panelists are given an opportunity to clarify both the information and their opinions about its relative importance on the raised issues. The stage 4: it is normally the final stage, the list of pending issues, its priorities, and the minority opinions, and the issues on which consensus was reached are distributed to the panelists. This stage provides a final opportunity to participants to review their opinions. The number of iterations depends largely on the degree of the consensus desired by researchers and may vary from three to five cycles.

Nieuwmeijer (1992) defines negotiation as a basic way for an involved party can get what it wants from the other one, through a process of communication and information exchange that aims to reach an agreement between the involved parties, who agree on common goals and disagree on others. Although the concept of negotiation has been studied extensively, researchers agree on it is a strategic planning process, communication and agreements 
implementation, which, according to the nature of the used strategy, it is divided in an integrative approach that is collaborative and seeks the maximum gain with minimum possible losses between the parties involved and under a distributive approach, which is competitive and involves a maximum gain of one of the parties without considering the position of the other one (Gulliver, 1979; Pruitt, 1981; Zartman \& Berman, 1982; Bazerman \& Lewicki, 1983). From the communication process perspective Bostrom (1983) adds that there is persuasion as a key component of the negotiation, while Susskind et al., (1999) include mediation in which the agreements are reached with the support of an external third party with no interest in the conflict, in addition to the arbitration, that is similarly based on the intervention of a third party that at the end decides the deal to agree, in some cases it may be obligatory or voluntary.

However, traditionally a procedure that has been widely adopted by various deliberative assemblies, among which are parliamentary groups, legislative committees, mass meetings, etc., by which it is allowed to the majority to make decisions with effectiveness and efficiency, through a voting and special rules of order that determine the will of the assembly (majority rule), while ensuring the right for each one of the members of minorities to express their opinion, is the procedure known as Robert's Rules of Order (Henry \& Sarah, 2011). However, in contrast to this technique and of increasing popularity for its collaborative nature, there are models of consensus building, which, through an integrated approach they seek to achieve agreements that best represent the interests of the group (Susskind et al. 1999, Butler, 2001; Dressler, 2006), that despite their affinity in its early stages, as determined by the Society of Professionals in Dispute Resolution (1997) and Susskind et al., (1999) they should be adapted and made up to political frameworks and particular contexts where they will be applied.

From a sociological perspective, the importance of consensus for Durkheim, cited in Giddens \& Griffiths (2006), who envisions the society as a set of interdependent parts, it is its necessary living together in harmony, otherwise, the life of society will be under threat, while from the political perspective, Durand (2004), states that the substantial of consensus lies in its democratic value, on which it is defined a space of uncertainty, plurality and diversity, where conflict can be resolved through negotiation and assumed rules by all and not through appealing to a divine authority or other source. From the administrative perspective in organizations, the consensus is conceived into the interior as a strategic management tool for cohesion in the achievement of business objectives (Kellermanns et al., 2005) and between organizations, as a decision-making process that solves conflicts and disputes between various parties involved (Lámbarry, Rivas \& Peña, 2009).

Thus, within the context of public transport, particularly in the implementation of a BRT system that supplants concessioned half obsolete and deficient transport, as particularly often are the cases of Latin American cities that have required the support, participation and involvement of various actors with the intention of minimizing political opposition to the project and increasing public support for its successful implementation (Ardila, 2004; Wright, 2005, Institute for Transportation and Development Policy, 2007), among which there are two key groups of interests, related to the public, between those are the users of public transport and the general public and those related to privates who are actively involved in the provision or regulation of transport services whether public or private.

However, Wright (2001) has pointed out from the experiences in implementing these bus rapid transit systems in Latin America, as primary the political and technical will before the availability of capital, with business schemes that encourage public-private alliances on issues such as financing, implementation, and related to the operation of the system (Hook, 2005; Menckhoff, 2005, Institute for Transportation and Development Policy 2007; Lámbarry \& Rivas 2011).

Typically, as noted by Ardila (2004) and the Institute for Transportation and Development Policy (2007), the most complicated negotiations on the implementation of a BRT system are with the existing concessioned operators, who in many developing countries are a sector that operates in the informal economy, who are not used to government supervision, or to contribute with tax payment, there are organizations, emphasizes Iracheta (2006), that in some countries have proliferated and have been built based on political relations and the granting of concessions without bidding processes. In most cases, the vehicle which provides the service is operated under rental schemes where the driver does not own it and have to pay for its operation, earning the incomes and its own according to the number of passengers, which is known as the penny war that leads to problematic, risky and unsafe consequences for users, pedestrians and people in general (German Technical Cooperation Agency, 2003).

The BRT systems planning models coincide in some of its phases, that for political purposes it is advisable to involve, to existing concessioners that operates on a route on which it will be the line of the corridor, to the new 
transportation system, but also as critical the way they will be included, first, if they are not included at all, they will politically resist the system, while on the other hand, they should not be granted with veto power over design or hiring decisions. Among these models, in the light of international literature, stands out: the German Technical Cooperation Agency (2003), the Federal Transit Administration (2003), Centro de Transporte Sustentable (2005) and the Institute for Transportation and Development Policy (2007), however, these models make little emphasis on the establishment of agreements between the key groups involved, while the consensus building models that predominate by its empirical evidence are: Dalkey-Helmer (1963), Tree Bressen (1984), Butler (1987), Canadian Round Tables (1996), Susskind (1999), Seeds for Change (2009), same that are not documented despite the prominence and importance that public transport has on the international agenda, to strengthen joint arrangements between the interested parties at implementing a BRT system. Here are the consensus building models previously mentioned.

\subsection{Dalkey Helmer Model (1963)}

It is a method concerning to the use of expert opinion, based on the Delphi technique. The original objective of the method is to obtain a more reliable consensus opinion by a group of experts through a series of questionnaires interspersed with a controlled feedback process. It is considered as a method of consensus building by using a series of questionnaires that collect data from a selected experts panel (Turoff et al., 2002). Delphi, in its conventional version, usually experiences four distinct phases

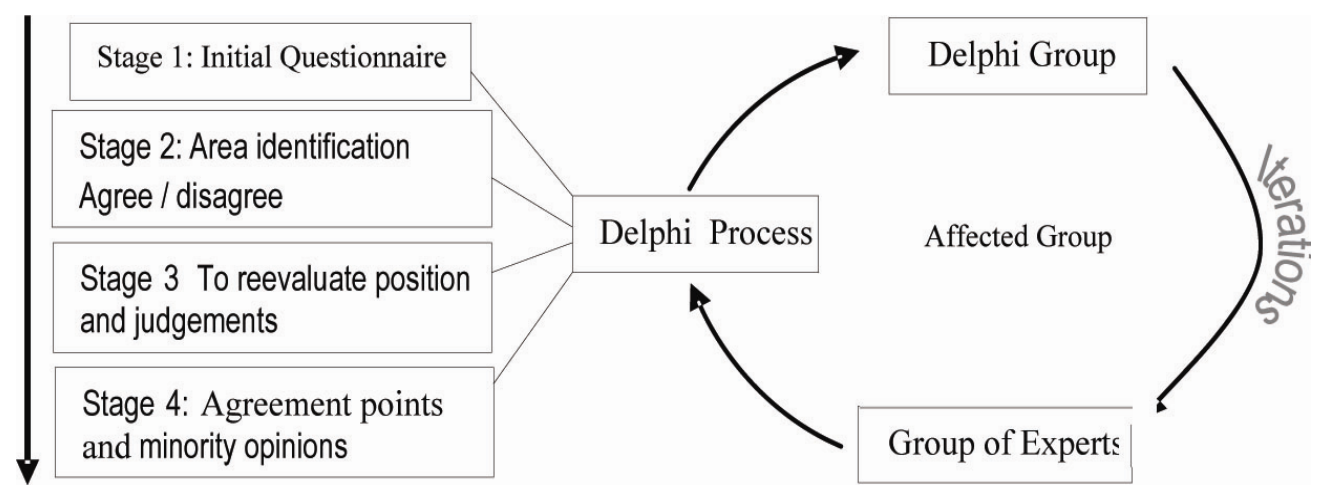

Figure 3. Dalkey helmer model - Delphi tecnique

Source: Own ellaboration from Turoff et al. (2002).

Turoff and Linstone (2002), identify on the Delphi process design three types of panels, on which it is established the communication process, which are:

1) Delphi: Formed by the facilitators, mediators and moderators, who with their abilities to clarify, synthesize and organize, stimulate, the communication process.

2) Experts: Specialist on the field or with relevant experience.

3) Involved: Those who are or will be directly affected.

\subsection{Tree Bressen Model (1984)}

Defines consensus as a method of joint search for solutions that best meet the collective needs of the group, in which all participants must agree before any action is taken. The process begins with the presentation of the issues or proposals, the background and objectives of the debate. 


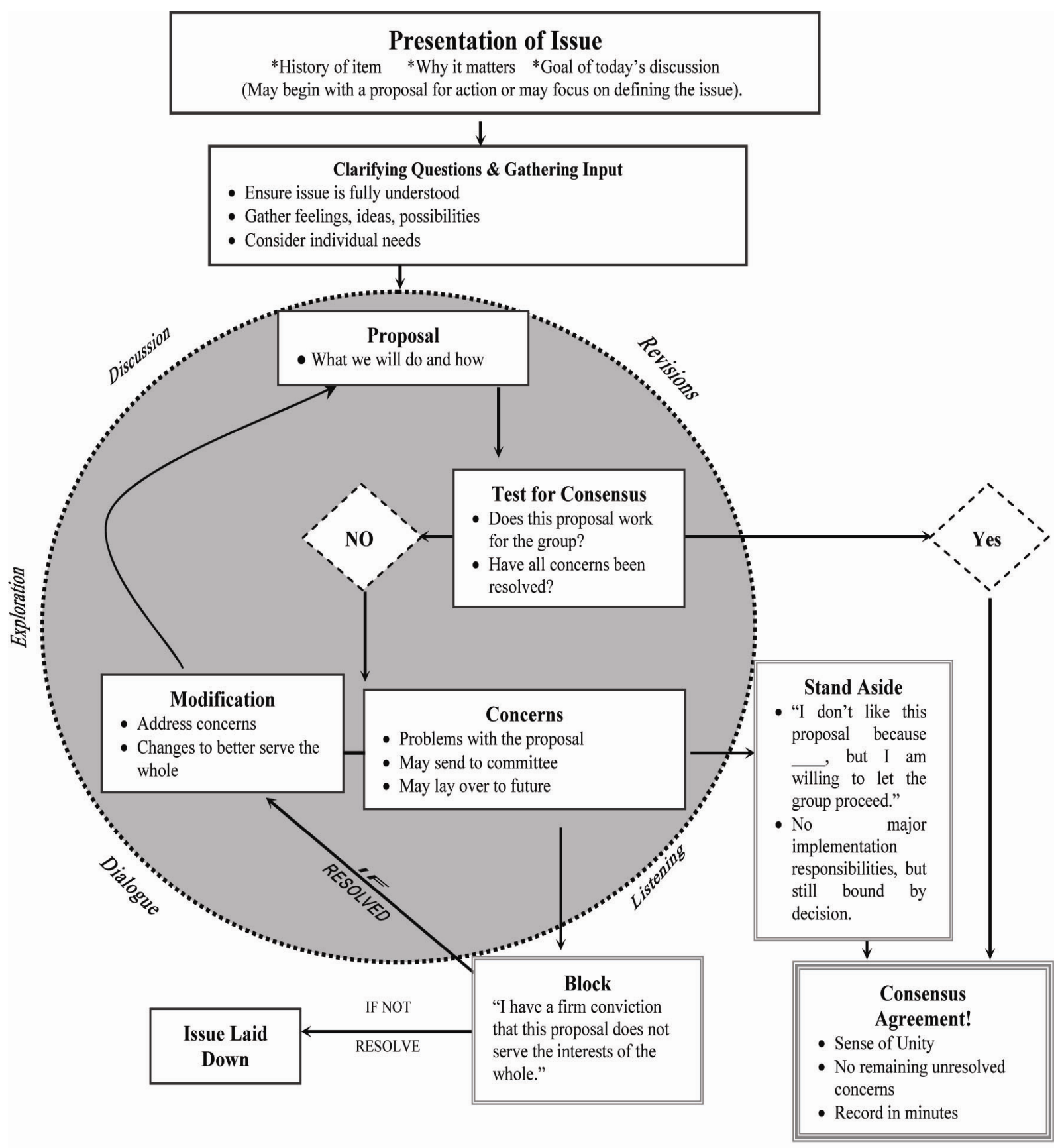

Figure 4. Tree bressen consensus model

Source: Tree Bressen (1984).

The facilitator integrates the comments giving a sense of direction, at this point it will make clear that, if the process is blocked, the issue should be sent to a committee. This model considers total empowerment of the participants on the decisions, including attentive listening, respect to disagreement, and the provision of more time if necessary before the agreement, with the aim of ensuring maximum support and conviction.

There are three answers for each of the participants when deciding:

1) Agreement: from certain tolerance to very enthusiastic.

2) To set aside: this choice is given for reasons of conscience or significant differences of opinion. It allows the group to continue the discussion of concerns and proposals. 
3) Blocking: This will provide participants, authority to prevent the group to take actions, only if the proposal is perceived to be contrary to the core values of the group or it jeopardizes the attainment of its objective. Any participant considering this option, will be ought to present and explain thoroughly the reasons for blocking and to work hard to find an acceptable solution.

\subsection{Butler Model (1987)}

Conceptualizes consensus as a cooperative dynamic procedure, where each proposal is considered at a time and each of the participants works together to make the best decision for the group. The formal consensus is presented in levels or circles

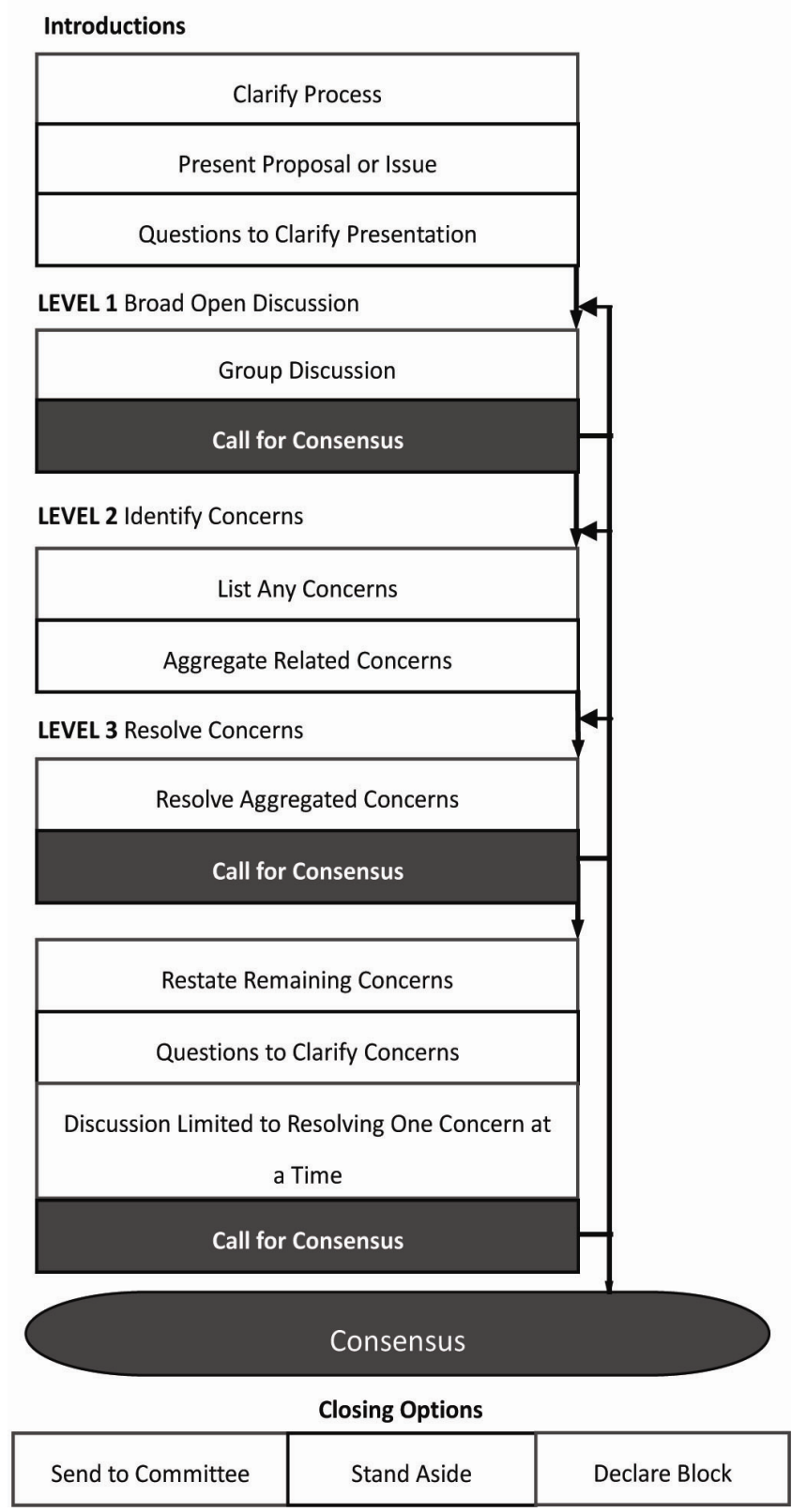

Figure 5. The process of formal consensus

Source: Butler, (1987).

The purpose of the first level is to allow everyone to freely express their perspective and concerns without beginning to solve them and debate is allowed. At second level, the scope of the debate is limited to identifying the concerns and interests of participants, so as to allow all participants to have a vision of them. It is up to the 
third level of the structure where they begin to explore solutions, the scope is therefore to solve each slope and concern.

As closing alternatives it is presented to send to a committee that represents the participants interests and includes all points of view, where it will be analyzed and it will be worked on creative solutions to be considered by all interested. When it hasn't been reached an agreement, it is appropriate that the facilitator asks the participants if they are willing to set it aside, admitting that the concern exists but that the proposal whether it is accepted or finally if consensus hasn't been reached, the proposal then is blocked and scheduled for an upcoming meeting.

\subsection{Canadian Round Tables Model (1996)}

It establishes a set of principles and key steps to make work the consensus processes, with the aim of achieving a sustainable future. It considers that building a sustainable future requires processes that reconcile competing interests, to plan cooperative alliances and to explore innovative solutions. Thus, the consensus process encourages solutions to complex problems through a combination of various fields of knowledge, as well as experts and participants, who work on the design of a process that maximizes their skills and solve their differences. Consensus, provides participants the opportunity to work together as equals in the realization of acceptable actions or outcomes, without the imposition of points of view or authoritarians of one group over another, even when it is not reached, the process crystallizes the discussions, clarifies the underlying issues, identifies agreement options and builds respect and understanding between the concerned parties. The Canadian Round Tables indicates that consensus is not a single process, as it is determined by the needs, abilities, interests, circumstances and issues of each situation. On this sense, describes the principles that can guide this process, which are:

a) Definite purpose: people need a reason to participate in the process.

b) Inclusive not exclusive: everyone involved with a significant interest on the matter should be considered in the consensus process.

c) Voluntary participation: the affected or interested participate voluntarily.

d) Own design: the parties design the consensus process

e) Flexibility.

f) Equal Opportunity: everyone should have equal access to relevant information and opportunity to participate on the proceedings.

g) Respect for diversity of interests: to accept values diversity, interests and awareness of the parties involved in the consensus process are essentials.

h) Responsibility: Stakeholders are responsible for their members and the procedure they agree to establish.

i) Time limit: it is necessary to establish realistic deadlines of the process.

j) Implementation: commitment to the implementation and effective supervision.

\subsection{Susskind Model (1999)}

Susskind (1999) defines consensus as a specific process of decision making that requires a structure and set of techniques to make more productive and efficient the discussions of the work groups, in order to build agreements and tailored them according to each specific situation. The model is implemented through a five step process that provides a reference framework to solve problems and make decisions in a wide variety of circumstances. 


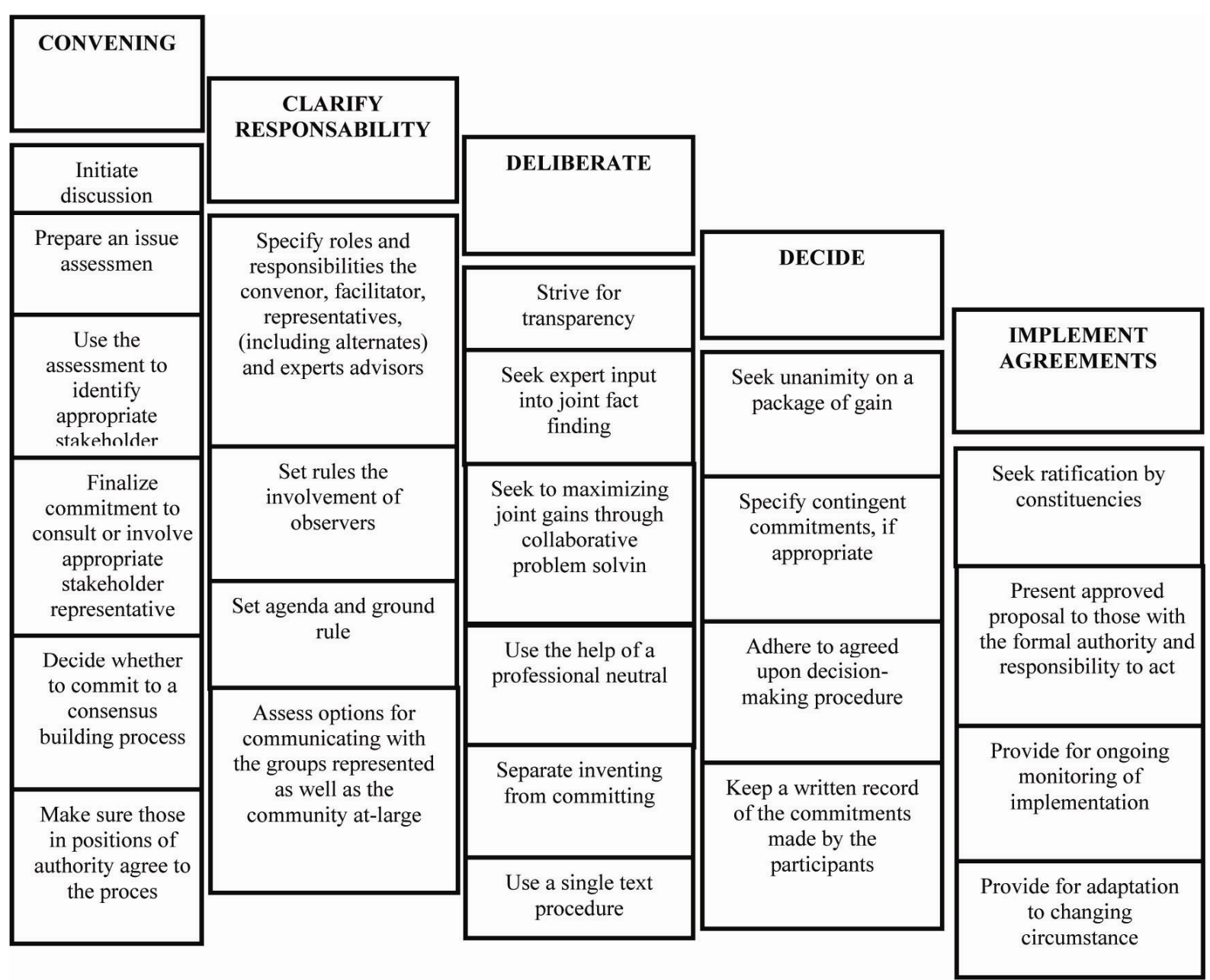

Source: Susskind (1999).

Figure 6. Five step process to consensus building

As a multi-contextual model in consideration of the issues and topics on which it can be used, it always look for consensual basis that supposes the participation of diverse people in search for agreements and conflict management that best meet the interests of the group in general. The method incorporates the figure of the mediator and / or facilitator in the process.

1) To convene: it is the initial part of any process of consensus building, in most cases this role can be exercised by consultants or by those interested on it. This stage generates the assessment of conflict, it will also include the professional advice of the assessor considering the feasibility or not of reaching agreements in the process.

2) To clarify responsibilities: on the first meeting are established the responsibilities of the participants, the supplants, the mediator and the observers (in case they are decided to be admitted) there are documented the basic rules that describe how decisions will be taken, it will inform the general public and the media. It is indispensable the record of the debates and to create a "group memory", showing the current process progress.

3) To Dialogue: every meeting is scheduled in accordance with the established agenda. The mediator works with the participants to prepare reference material, he will call for experts and lead the discussions. All participants must approve the memorandums of the meeting before starting another meeting. It is considered the combination of scientific and technical information that the parties decide to incorporate to the dialogue and a list of potential participants in the debate, with no interest in the conflict to serve as counselors.

4) To decide: The mediator shall prepare a draft agreement, which will be shown to each participant with the intention of suggesting improvements to maximize the possible consensus. The mediator will seek solutions that are acceptable to all the involved. It would be difficult to establish a consensus if less than $80 \%$ of participants in a group does not agree. Each representative will sign the agreement and it will be ratified by their constituents, 
which were kept informed about the debate progress

5) To implement agreements: The consensus does not end with the agreements generation, the implementation is part of the process. An interesting point that should be set as a final agreement is the supervision, in case that the agreements due to the contingencies needed some adjustments.

\subsection{Seeds for Change Model (2009)}

Defines consensus as a decision-making creative and inclusive process, rather than simply voting on a particular issue and choosing to have the majority group on a direction of an specific address option.

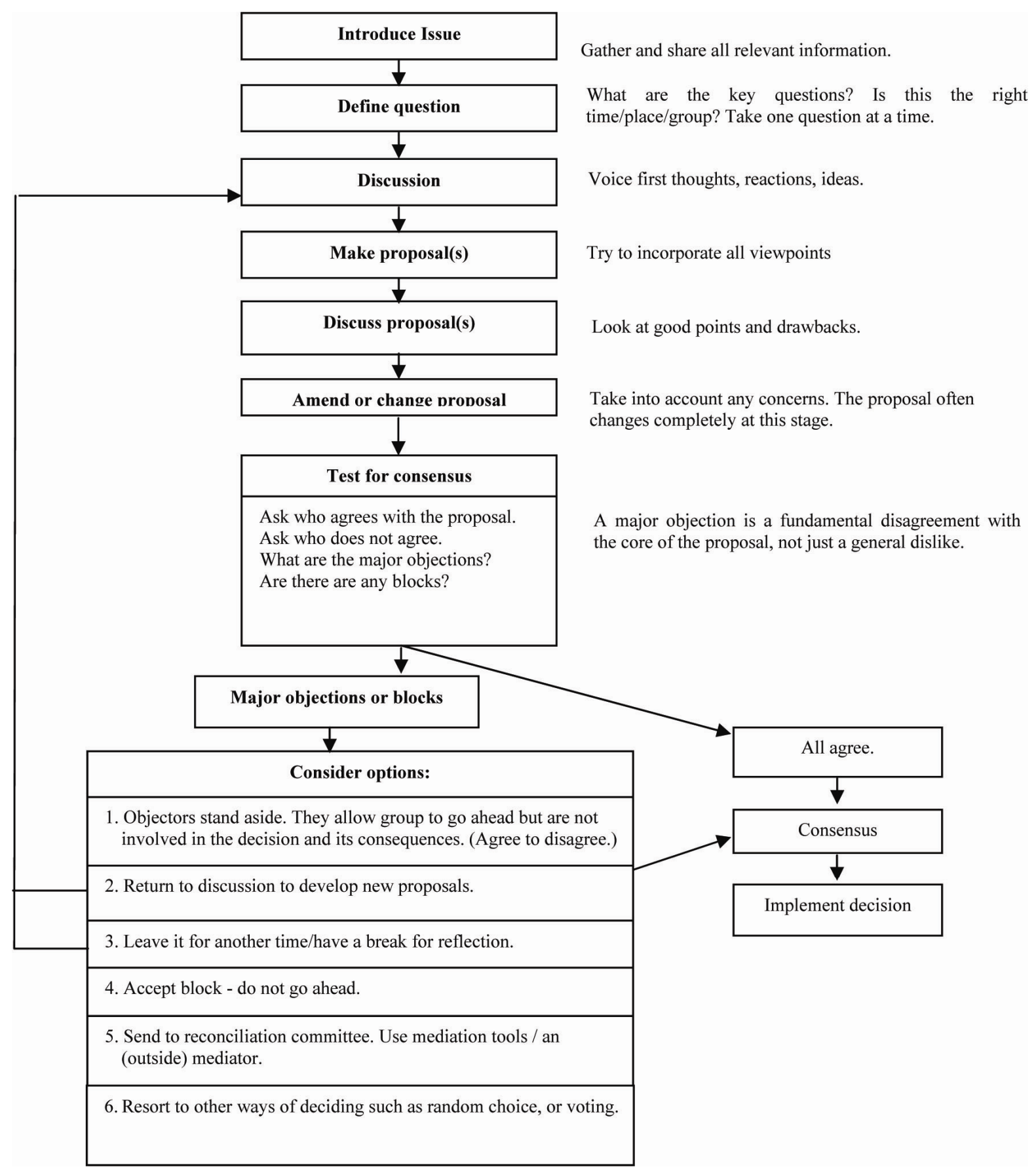

Figure 7. Seeds for change model

Source: Seeds for Change (2009). 
Which ensures that the opinions and ideas of the participants are taken into account. The group is committed to find solutions where everyone can live with it.

The model establishes some conditions to reach a consensus, among which are:

1) Common goal: Each participant needs to unite for common goals, to be clear that shared objectives keep the meetings focused and in conjunction.

2) Commitment to achieve consensus on all decisions: the consensus requires commitment, patience, tolerance and willingness to put up front the interests of the group.

3) Trust and respect: it is necessary to trust that each participant shares the personal commitment and respects the opinions and rights.

4) Clear processes: all participants must understand the established process to decide, it is necessary to explain the process at the beginning of the meeting.

5) Active participation: those involved must have an active role in the process.

6) Adequate provision: to help the group to work harmoniously, creatively and democratically.

\section{Analysis}

The following is an analysis of the models presented above, we have considered the phases under which a proposal from the authors of this study include those most representative of the common principles or guidelines of the models, but also those differentiated between them but significant. Which can be grouped in categories (stages) that are displayed in Table 1, and the variables associated with the cell in question.

Table 1. Models comparative according to phases

\begin{tabular}{|c|c|c|c|c|c|c|c|}
\hline Model/Stage & Agree & Responsibilities & Deliberate & Decide & Implement & Closing alternatives & To Convene \\
\hline Dalkey Halmer & $\begin{array}{l}\text { Experts group, facilitator, } \\
\text { mediator and moderator. }\end{array}$ & $\begin{array}{l}\text { Knowledge of the } \\
\text { procedure. }\end{array}$ & Questionaire & $\begin{array}{l}\text { Iterative process through } \\
\text { questionaires. }\end{array}$ & Not considered. & Not considered. & $\begin{array}{l}\text { The number of } \\
\text { iterations defines the } \\
\text { level of wished } \\
\text { consensus }\end{array}$ \\
\hline Tree Bressen & $\begin{array}{lr}\text { Facilitator that } & \text { presents } \\
\text { topics, } & \text { gathers } \\
\text { contributions } & \text { integers } \\
\text { comments. } & \end{array}$ & $\begin{array}{l}\text { Considers total faculty } \\
\text { of the attendants in the } \\
\text { decisions. Id the } \\
\text { process is blocked, the } \\
\text { topic must be sent to a } \\
\text { committee. }\end{array}$ & $\begin{array}{l}\text { Dialogue, listen, } \\
\text { debate, review. }\end{array}$ & $\begin{array}{l}\text { There are three answers } \\
\text { to each attentdant when } \\
\text { deciding: } \\
\text { Agree. } \\
\text { Put aside. } \\
\text { Block. }\end{array}$ & Not considered. & $\begin{array}{ll} & \\
\text { Put aside. } & \\
\text { Block: } & \text { excluded } \\
\text { topic. } & \end{array}$ & $\begin{array}{l}\text { Evaluates the } \\
\text { consensus if the } \\
\text { proposal is appropiate } \\
\text { and the concerns } \\
\text { atended. }\end{array}$ \\
\hline Buttler & $\begin{array}{l}\text { Facilitators and experts in } \\
\text { the formation of a } \\
\text { committee. }\end{array}$ & The process is clarified & $\begin{array}{l}\text { Three levels: totally } \\
\text { open discussion, } \\
\text { interests } \\
\text { identification and } \\
\text { concerns solution. }\end{array}$ & $\begin{array}{l}\text { Totally open group } \\
\text { debate. }\end{array}$ & Not considered. & $\begin{array}{l}\text { Put aside. } \\
\text { Send to committee. } \\
\text { Declared blocked. }\end{array}$ & $\begin{array}{l}\text { The formal consensus } \\
\text { is shown in levels or } \\
\text { circles in which } \\
\text { consensus } \\
\text { convened. }\end{array}$ \\
\hline $\begin{array}{l}\text { Canadian } \\
\text { Round Tables }\end{array}$ & $\begin{array}{l}\text { Experts and attendants } \\
\text { who work in the design of } \\
\text { a process that maximizes } \\
\text { their skills and resolves } \\
\text { their differences. }\end{array}$ & $\begin{array}{l}\text { The affected and } \\
\text { interested ones } \\
\text { participate voluntarily, } \\
\text { they are who design the } \\
\text { consensus process. The } \\
\text { interested parties are } \\
\text { the ones responsable for } \\
\text { their members and the } \\
\text { procedure they agree to } \\
\text { stablish. }\end{array}$ & $\begin{array}{l}\text { The process clarifies } \\
\text { the discussions, } \\
\text { underlying issues, } \\
\text { identifies the } \\
\text { agreement options } \\
\text { and builds respect } \\
\text { and understanding } \\
\text { among affected } \\
\text { parties. }\end{array}$ & $\begin{array}{l}\text { Opportunity to work } \\
\text { together as equal in the } \\
\text { making of aceptable } \\
\text { actions and results, } \\
\text { without the imposition of } \\
\text { points of view or } \\
\text { authoritary ones from } \\
\text { one group upon the } \\
\text { other. }\end{array}$ & $\begin{array}{l}\text { Commitment to } \\
\text { an affective } \\
\text { implementation } \\
\text { and supervisión. }\end{array}$ & Not considered. & $\begin{array}{l}\text { It describes ten } \\
\text { principles that can } \\
\text { lead the consensus } \\
\text { process. Only at the } \\
\text { end it considers the } \\
\text { consensus } \\
\text { implementation. }\end{array}$ \\
\hline Susskind & $\begin{array}{l}\text { It can be exercised by } \\
\text { consultancies or those } \\
\text { interested in it. } \\
\text { Initiate dialogue, conflicto } \\
\text { assessment, adviser } \\
\text { recomendation } \\
\text { considering the feasibility } \\
\text { of reaching or not } \\
\text { reaching agreements. } \\
\text { Identification of the } \\
\text { interested parties } \\
\text { representatives, finding } \\
\text { financing of the process. }\end{array}$ & $\begin{array}{l}\text { Stablishing the roles of } \\
\text { the facilitators, } \\
\text { mediators and } \\
\text { attendants, besides the } \\
\text { decission process } \\
\text { observer rules and the } \\
\text { communications } \\
\text { options. }\end{array}$ & $\begin{array}{l}\text { To maintain } \\
\text { transparency, to seek } \\
\text { for experts advise, to } \\
\text { create } \\
\text { subcommittees. }\end{array}$ & $\begin{array}{l}\text { To maximize joined } \\
\text { earnings, to follow the } \\
\text { rules adopted for } \\
\text { decission making, to log } \\
\text { process and decissions } \\
\text { information. }\end{array}$ & $\begin{array}{l}\text { Represented } \\
\text { ones ratification. } \\
\text { Monitoring as } \\
\text { part of the } \\
\text { agreements } \\
\text { implementation, } \\
\text { adjustments due } \\
\text { to contigencies. }\end{array}$ & Not applicable. & $\begin{array}{l}\text { The model is } \\
\text { implemented } \\
\text { through a five } \\
\text { step process. The } \\
\text { last one is } \\
\text { implementation. }\end{array}$ \\
\hline $\begin{array}{l}\text { Seeds } \\
\text { Change }\end{array}$ & Presenting the topics. & $\begin{array}{l}\text { To define the key } \\
\text { questionaires. }\end{array}$ & $\begin{array}{l}\text { To consider thougths } \\
\text { reactions and ideas } \\
\text { among participants. } \\
\text { To make proposals. }\end{array}$ & $\begin{array}{l}\text { To test the consensus } \\
\text { (agreement, objections } \\
\text { or blocks). }\end{array}$ & $\begin{array}{l}\text { To implement } \\
\text { the decission (it } \\
\text { does not show } \\
\text { guidelines). }\end{array}$ & $\begin{array}{l}\text { Main objections or } \\
\text { blocks: to go back to } \\
\text { debate new proposal, not } \\
\text { moving forward, to send } \\
\text { a conciliation committee, } \\
\text { other random decission or } \\
\text { voting options. }\end{array}$ & $\begin{array}{llr} & \text { Only one } \\
\text { o } & \text { questioning is } \\
\text { d } & \text { considered at a } \\
\text { time, within a } \\
\text { sequential } \\
\text { procedure. }\end{array}$ \\
\hline
\end{tabular}

Source: own ellaborated.

In general, the consensus building models agree on involving facilitators and experts as part of the phase called to convene, only the Susskind model points out further to consider the identification of representatives of the 
interested parties that in the case under study, is usually essential. In the category of clarifying responsibilities, the rules to be followed in the decision making process are agreed, the rules for the observers and to the communication options (media). At this stage, the models agree that the procedures to follow to build the agreements should be clear.

In the deliberate phase of the proposals are made so that crystallize the discussions, the underlying issues are clarified and identifies the options for agreement and understanding between the concerned parties. There are considered the feedback and ideas among participants, maintaining transparency and it is possible to seek the advice of experts and / or the creation of subcommittees to divide the subjects.

On the deciding stage it is seeked to maximize joint profits among those involved by following the adopted rules for the decision-making process and the agreements are recorded. On this phase, they work together as equals in achieving acceptable actions or outcomes without the imposition of points of view or authoritarians of one group over another. It calls for consensus test, the objections or the blocking of the proposals.

The deployment sequence in only three of the six models is distinguished, but mainly in two of them, the Canadian Round Tables and Susskind, however, that in the case of BRT systems consensus it is an inevitable phase of the need of a new sustainable transport system, so there must be a commitment to implementation, effective supervision procedures and monitoring the agreed. In this stage it should be pondered some adjustments due to contingencies that will arise. The models: Dalkey Halmer, Tree Bressen and Butler, have this vacuum, of carrying out the built consensus.

In the closing alternatives phase, there are the main objections or proposals blocking, one possibility is to return to discuss further suggestions, send a reconciliation committee, look for other random decision or voting options, or to declare the proposal blocked or to exclude the issue. Dalkey Halmer, Canadian Round Tables and Susskind models, do not emphasize any alternative in case of not reaching agreements on a proposal, although the latest one presents the use of contingencies on its decision phases.

\section{Conclusions}

It is possible to conclude on this research the following:

The BRT systems planning models, among which outstand: the one from the German Technical Cooperation Agency (2003), the Federal Transit Administration (2003), Centro de Transporte Sustentable (2005) and the Institute for Transportation and Development Policy (2007), however, while these models emphasize consensus, they do not guide on its building processes.

1) The consensus building models that prevails dominated by its empirical evidence are: Dalkey-Halmer (1963), Tree Bressen (1984), Butler (1987), Canadian Round Tables (1996), Susskind (1999), Seeds for Change (2009), same that are not documented about the cases of implementation of BRT systems to strengthen joint arrangements between the parties concerned, despite the prominence and importance that public transport has on the international agenda.

2) The stages in building consensus models, according to the analysis done, agree under an item in the following classification:
a) To convene.
b) Responsibilities.
c) To dialogue.
d) To decide.
e) To deploy.
f) Closing alternatives.

3) Only the Susskind consensus building model gives importance, on its convening stage, to identify interested groups as an essential part in the conflict assessment to determine whether to make the process or not, it foresees a closing alternative in case of not reaching any agreement on a particular proposal. Similarly, the bus rapid transit planning systems models, concur in its initial phase that it is essential to carry out an analysis of key groups involved, among them are primarily identified the concessioner operators as the toughest group to negotiate with and it is necessary to include at least one affected operator. Therefore, it is a stage that should be emphasized in consensus building models and prior to the start of the process, as shown in the proposed model in Figure 8 . Proposal developed particularly to establish joint agreements between two interested parties: the existing affected operators and government officials responsible for its implementation. 


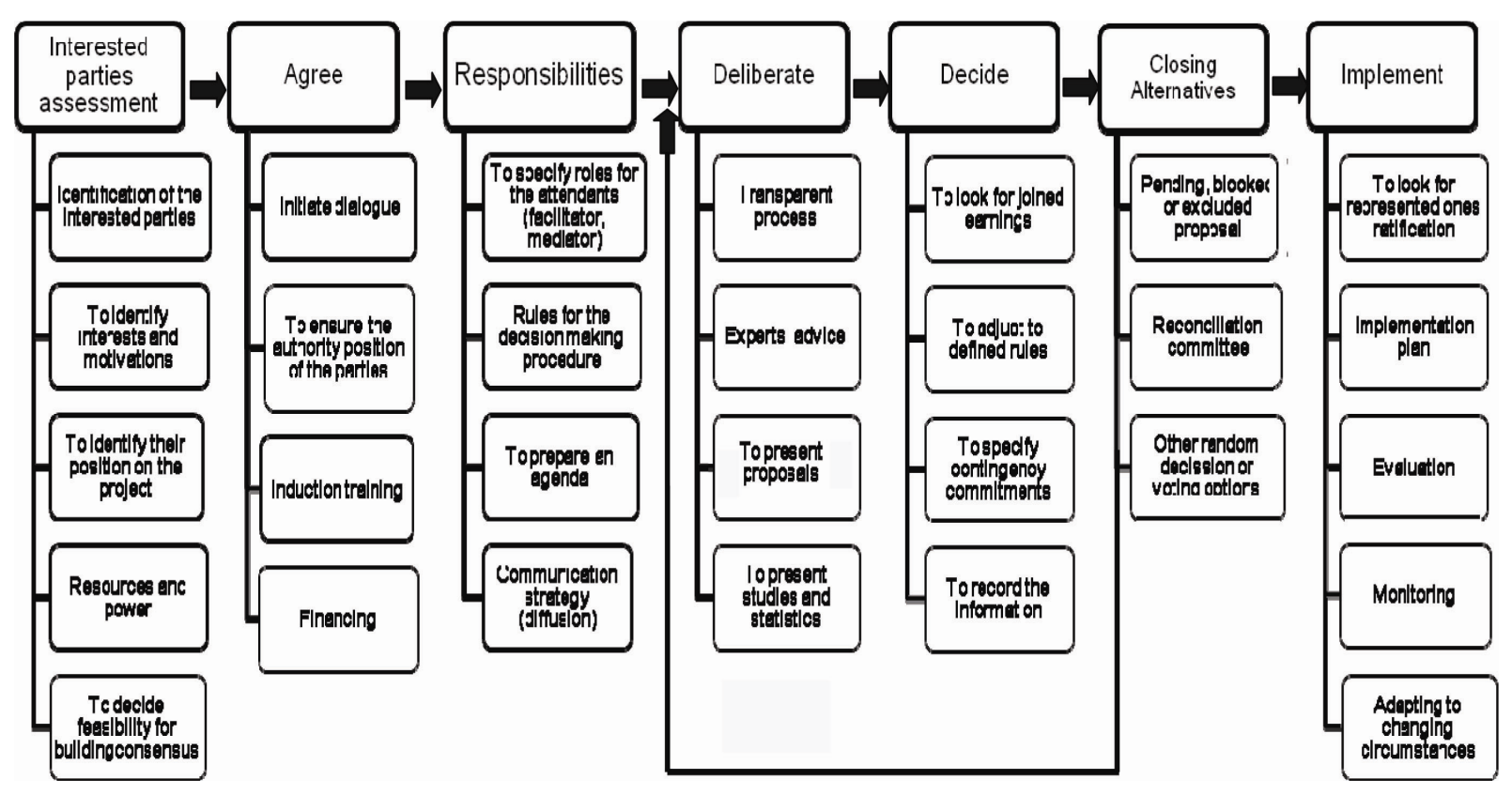

Figure 8. BRT theoretical consensus building model

Source: own ellaborated.

Interested parties assestment: It is the initial part of the consensus building process on the implementation of a bus rapid transit system. These interested parties include: the government, transportation, environmental, public infrastructure, public health, among others departments. Private sector: the existing transport operators, the construction, bonding and insurance, telecommunications services and water industries. Industrial complexes and public services business centers: schools, universities and hospitals. Civil society: environmental NGOs, internationals and foundations. User groups: cars owners, public transport users and people with disabilities (German Technical Cooperation Agency, 2003). The strategy must be developed, considering the possible positions of interest that may be undertaken by those involved depending on the potential impact degree (negatively or positively), which can be supportive, moderate support, neutral, moderate opposition and of opposition.

However, as indicated by the Institute for Transportation Policies and Development (2007), the most complicated negotiations on the implementation of a BRT system are with the existing concessioner operators which should be identified the resources they have, their share percentage of demand served on the stroke of the corridor, his power of influence in the transport sector, their situation regarding to their accreditation and / or validity of the license operating at the time (to identify private operators that can be revoked on their license) a valid concession of a private operator could block the BRT project in court for years (Institute for Transportation and Development Policy, 2007; Lámbarry \& Rivas, 2011). On this stage the recommendation will be included (in case that it has been adopted by a professional of the counselor, or on a recommendation of who carries out the process) on the feasibility or not of reaching agreements in the process, therefore, the individual or organism that has summoned will determine whether or not to initiate the consensus building process as the organizations and individuals that feel threatened by the new system can act by hindering the project until the interruption of its implementation.

To agree: It starts formal dialogue, which can be done individually or collectively, this role can be exercised by consultants or by those interested in it, in most cases is the governing authority on public transport who performs individually the negotiation with each concessioner operator (Lámbarry \& Rivas, 2011). Normally, the concessioners lack of professional training and operate informally, in addition to their knowledge about the BRT system in general, tend to be scarce, it is necessary to train them on an introductory way to this mode of transport and about business principles so they formalize their operations. It is advisable to seek financing for mediation or negotiation process, in case of it has been hired a consulting firm.

To clarify responsibilities: in the first meeting there are settled the participants, alternates, the mediator (facilitation techniques to assist the parties in their efforts to solve problems and thereby, guide the process) and 
observers (in case it is decided to admit them) responsibilities, basic rules are documented that describe how decisions will be made, how it will be reported to the public in general and the media. The group should handle a book that describes the order of matters to be discussed; it is also indispensable the record of the discussions and to create a "group memory", showing the process progress. Mediators, the ground rules and agenda must be approved unanimously by the participants, reducing the chances of finding serious barriers in consensus building. The communication strategy is necessary under two aspects, firstly, focused on the main involved (identified operators) about successful cases, benefits, advantages and details of the system, talks and press conferences of other BRT systems representatives that it is similarly directed to the general public and to support the educational and informative process of the new transport model (Institute for Transportation and Development Policy, 2007). Once it is made the political commitment and the announcement of the BRT implementation, it will immediately be public interest in the project (Ardila, 2004), therefore it must be articulated a comprehensive communication strategy, but first it must be evaluated the interests of the main involved parties.

To dialogue: Every meeting is scheduled in accordance with the established schedule. All participants must approve the minutes of the meeting before starting another meeting. It is considered the combination of technical studies and statistics that the parties decide to incorporate to the dialogue (supply demand balance, load polygons, visual frequency of passengers, etc..) As well as expert advice on the topics covered, under a clear process. There are presented the proposals to be discussed, that particularly in the case under study, they are usually about the business model, the physical structure, the service operation structure and the BRT system evaluation.

To decide: The mediator will prepare a draft agreement that will be displayed to each participant with the intention of suggesting improvements to maximize the possible consensus. The mediator will seek solutions that are acceptable to all the involved and on which, it will be sought to negotiate with each of the parties, according to their relative and subjective importance (value), producing a joint profit (mutual) that increases the level of satisfaction. It will be difficult to establish consensus if less than $80 \%$ of participants in a group disagree (Susskind, 1999). Each representative will sign the agreement and $t$ will be ratified by their constituents, which were kept informed of the debate progress. On this phase it will be included some specifications in consideration of contingencies.

The international experience in the case of BRT implementation, notes that the consensus on the proposals presented in the previous phase, usually are through the redefinition of the new responsibilities and schemes of public-private alliances (Lámbarry \& Rivas, 2011):

1) Business Model (German Technical Cooperation Agency, 2003; Ardila, 2004, Centro de Transporte Sustentable, 2005, Institute for Transportation and Development Policy, 2007, Hidalgo, 2007):

a. Toll system and access control: concession to others and fee collect (set by the Government).

b. Establishment of a Trust: concentration and distribution of the corridor's resources according to the priority of payments set the trust contract between the following areas: trust services, toll system and access control, credit for the buses payment related services to the insurgents corridor, feeder services, operators companies, regulator entity services, contingent and reserve funds and others approved by the trust's technical committee.

c. Training and participation of the operating companies: share-based, payment in relation to the number of the service driven miles (weekly reconciled in the operating companies committee), application of deductions or the respective bonuses, weekly payment, additional revenue from advertising spaces leasing inside their buses in accordance with the provisions of the system image manual.

d. Constitution and income of the regulator entity: by its participation in the planning, management and control of the corridor operation (typically decentralized government agency), obtained from the trust. Concessions and authorizations, with direct charge to the trust. In addition to other revenues, such as related services necessary for the service (the cost of the corridor's electrical energy, water, cleaning, maintenance and monitoring), the sale of image, brand usage and stations advertising.

e. Deductions: involving economic discounts that the regulator entity applies to the operating companies. Among they are the: related to the provision of the service, for reasons attributable to drivers, for deficiencies related to customer service, those relating to buses and infrastructure (storage yards and buses maintenance, facilities and equipment ) annexed.

2) Operation of the service structure (Ardila, 2004, Centro de Transporte Sustentable, 2005, Institute for Transportation and Development Policy, 2007):

a. Regulation, programming and control: regulator entity (service hours, operation programming, service 
interruption, performance indicators).

b. Operating companies committee, it will have the faculties: to review and propose changes to the operation of the service program, review and reconcile the data service mileage on the vehicle fleet review the results of the operation and, where appropriate, propose attention measures to deviations from the service schedule, needs assessment, definition, implementation process and results review of technical studies that are required, as well as the implementation of the measures, the review of operating costs, the review of payment indexing parameters per kilometer, balancing service programming among the operating companies, deductions and credits reconciliation to the operating companies, assist in the implementation of the operation rules, assist in updating information for service programming, to apperceive the operating companies, on the lack of timely delivery of service programming information, assessing the impact of external events in the operation and determination and mitigation actions determination.

c. Training: Annual training program for staff.

d. Guarantees and insurance: it includes major force risks and fortuitous event and liability insurance

e. Supervision, monitoring and control: the ability of the regulator entity, the operation supervision, the buses supervision, the infrastructure supervision, the toll access control supervision and the institutional programs supervision.

f. Feeder routes.

3) Physical Structure (Institute for Transportation Policies and Development, 2007, Centro de Transporte Sustentable, 2005):

a. Government Infrastructure: on charge of terminals, stations, confined railed, bases and launchers, but in some other cases third parties are concessioned.

b. Operating companies infrastructure: that has a storage yard, workshop and fuel supply station, mainly.

c. Vehicle Fleet: registry with the regulator entity, buses and drivers, in service and in reserve, technical and functional specifications by the regulator entity about the variable number of fleet according to the corridor's demand, fulfillment of the service operation program, certificate of homologation, maintenance system and program, lifetime 10 years, replacement of buses that do not meet the specifications, maintenance system, bus corridor image, buses current insurance policy of liability for damage to the user and third parties.

4) Assessment (Institute for Transportation and Development Policy, 2007).

a. Environmental Management Program: which includes a maintenance program (quality of workmanship, of the parts, pollutants program verification), hazardous waste management, waste-priority: fuel and lubricants.

Closing Alternatives: Although it is not desirable, this phase is proposed on the consensus building, to foresee the cases of some approaches that do not allow the process to continue, so they are excluded and / or sent to a conciliatory committee or they follow any other decision option, as long as they are not substantive, or to deploy to its debate again.

To implement agreements: the consensus does not end with the agreements generation, the implementation is part of the process, so, agreements should be linked to formal decisions and, if possible, in pursuit of public-social support, as well as to be ratified by the represented. An interesting point to be established as a final agreement is the evaluation and monitoring, in case of the agreements, due to contingencies needed adjustments.

\section{References}

Ardila, A. (2004). Transit Planning in Bogota and Curitiba: Roles in Interaccion, Risk and Change. Phd thesis, Boston: MIT.

Bazerman, M., \& Lewicki, R. (1983). Negotiating in organizations. Beverly Hills: Sage.

Bostrom, R. (1983). Persuasion. Englewood Cliffs, New Jersey: Prentice-Hall.

Butler, L., \& Rothstein, A. (2001). On Conflict and Consensus A Handbook on Formal Consensus Decisionmaking. USA: Food Not Bombs Publishing.

Canadian Round Tables. (1996). Building Consensus for a Sustainable Future. Putting Principles into Practice. Retrieved from http://www.nrtee-trnee.com/eng/publications/publications-by-date.php\#governance 
Center for Democracy and Governance. (1998). Alternative dispute resolution Practitioners' guide. Retrieved from http://.www.usaid.gov/our_work/democracy_and_governance/pdfs/pnacb895.pdf

Centro de Transporte Sustentable. (2009). Metrobús Bienvenidos a bordo. Movilidad Amable, AñoI(1). Retrieved from http://www.ctsmexico.org/node/22

Chadwick, B. (2002). Free conflict resolution training manual beyond Conflict to Consensus. Washington State. Retrieved from http://www.managingwholes.com/--consensus.htm

Dalkey, N., \& Helmer, O. (1963). An experimental application of the Delphi method to use of experts. Management Science, 9(3), 458-467.

Federal Transit Administration. (2003). Bus Rapid Transit Volume 2: Implementation Guideliness. Transit Cooperative Research Program Report 90, Washington, D.C. Retrieved from www.TRB.org

German Technical Cooperation Agency. (2003). Sustainable Transport: A Source Book for Policy-makers in Developing Cities Module 3a: Mass Transit options. Retrieved from http://www.gtz.de/en/themen/28264.htm

Gulliver T. (1979). Disputes and Negotiation: A Cross-cultural Perspective. New York: Academic Press.

Henry, M., \& Sarah R. (2011). Robert's Rules of Order Newly Revised (11th ed.). Philadelphia: Da Capo Press.

Hook, W. (2005). Institutional and regulatory options for bus rapid Transit in developing countries: Lesson from international experience. Retrieved from http://www.itdp.org/documents/BRT reform_TRB_05 rev oct.pdf

Innes, J., \& Booher, D. (2001). Planning with complexity: an introduction to collaborative rationality for public policy. New York: Taylor \& Francis e-Library.

Institute for Transportation and Development Policy. (2007). Bus Rapid Transit Planning Guide. Retrieved from www.itdp.org

Iracheta, A. (2006). La Necesidad de una Política Pública para el desarrollo de Sistemas Integrados de Transporte en las Grandes Ciudades Mexicanas. Retrieved from http://www.ctsmexico.org/archivos_pdf/SIT_pp.pdf

Jacobs, J. (1996). Essential assessment criteria for physical education teacher education programs: A Delphi study. Morgantown: West Virginia University.

Kellermanns, F., Walter, J., Lechner, C., \& Floyd S. (2005). The Lack of Consensus about Strategic Consensus: Advancing Theory and Research. Journal of Management, 31(5), 719-737. http://dx.doi.org/10.1177/0149206305279114

Lámbarry, F., \& Rivas, L. (2011). Modelo de planeación y consenso en los sistemas de autobuses de tránsito rápido: el caso de Metrobus en la Ciudad de México y Mexibus en el Estado de México. Tesis Doctoral. Escuela Superior de Comercio y Administración Santo Tomas. México.

Lámbarry, F., Rivas L., \& Peña, M. (2009). Modelos de decisión bajo una perspectiva de análisis de sus procesos. Universidad y Empresa, 18, 146-173.

Lámbarry, F., Rivas L., \& Trujillo, M. (2009). Efectos de la teoría de la complejidad en la gestión ambiental. México: Instituto Politécnico Nacional.

Ludwig, B. (1994). Internationalizing Extension: An exploration of the characteristics evident in a state university Extension system that achieves internationalization. Columbus: The Ohio State University. Retrieved from http://etd.ohiolink.edu/view.cgi?osu1146146542

Menckhoff, G. (2005). Latin American experince with bus rapid transit. Retrieved from http://www.gobrt.org/Latin_American_Experience_with_Bus_Rapid_Transit.pdf

Moore, C., Jayasundere, R., \& Thirunavukarasu, M. (sin año). The Mediation Process: Trainee's Manual Community Mediation Programme. Retrieved from htttp://www.justiceministry.gov.lk/images/TraineeEnglish final.pdf

Nieuwmeijer, L. (1992). Negotiation: Methodology and training. Pretoria: Human Sciences Research Council.

Petts, J. (1995). Waste Management Strategy Development: A Case Study of Community Involvement and Consensus-Building in Hampshire. Journal of Environmental Planning and Management, 38(4), 519-536. http://dx.doi.org/10.1080/09640569512797

Pidgeon, N., \& Henwood, K. (1997). Using grounded theory in psychological research. In En N. Hayes (ed.), 
Doing qualitative analysis in psychology (pp. 245-273). Hove, UK: Psychology Press.

Pruitt, D. (1981). Negotiation Behaviour. New York: Academic Press.

Regan H., Colyvan M., \& Markovchick, L. (2005). A formal model for consensus and negotiation in environmental management. Journal of Environmental Management, 80(2006), 167-176.

Seeds for Change. (2009). Consensus Decision Making. Retrieved from http://seedsforchange.org.uk/free/consensus

Society of Professionals in Dispute Resolution. (1997). Best Practices for Government Agencies Guidelines for Using Collaborative Agreement-Seeking Processes. Retrieved from http://www.corderthompson.com/documents/Guidelines for Using Collaborative Processes.pdf

Stauffer, D. (2001). The Sznajd model of consensus building with limited persuasion Cited by F Slanina, H Lavicka en Analytical results for the Sznajd model of opinion formation. The European Physical Journal B-Condensed Matter, 35, 279-288.

Stevens, C. (1963). Strategy and collective bargaining negotiation. New York: Mc Graw-Hill.

Susskind, L., McKearnan, S., \& Thomas-Larmer, J. (1999). The Consensus Building Handbook: A Comprehensive Guide to Reaching Agreement. USA: Sage Publications, Inc.

The Policy Consensus Initiative. (1999). A practical guide to consensus. Retrieved from http://www.policyconsensus.org/publications/practicalguide/index.html

Tree Bressen. (1984). Consensus Decision Making. In En Holman, P., Devane T., \& Cady, S. (Eds.), The change handbook. San Francisco, Ca: Berret-Koehler Publishers, Inc.

Turoff, M., Linstone, H., \& Helmer, O. (2002). The Delphi Method Techniques and Applications. Edited by Portland State University New Jersey Institute of Technology.

Van Den Belt, M. (2004). Mediated Modeling: A System Dynamics Approach To Environmental Consensus Building. USA: Island Press.

Wright, L. (2001). Latin american busways: moving people rather than cars. Retrieved from http://eprints.ucl.ac.uk/111/1/Latin_American_Busways,_Lloyd_Wright,_Natural_Rosurces_Forum,_May_ 2001.pdf

Wright, L. (2005). Sustainable transport: A sourcebook for policy-makers in developing cities, module 3b: bus rapid transit. Retrieved from http://www.itdp.org/read/brtplanningguieddec04.pdf_

Zartman I., \& Berman M. (1982). The practical negociator. New Haven, USA: Yale University. 